\title{
Kinetics from castor oil extraction using ethanol as solvent
}

\section{Cinética de extração de óleo de mamona empregando etanol como solvente}

\author{
Suzana Diel Boligon' \\ Ana Carolina Scher" \\ Bruno München Wenzel"I
}

\begin{abstract}
The sensitization for energy issues and environmental resulting from burning fossil fuels encourage the search for materials, inputs and renewable sources of energy. The biofuel is one of these renewable sources and is produced from vegetable oils extracted from raw material such as castor (Ricinus communis). It has been investigated as a raw material due to the high oil content in the seed, the possibility of plantations in regions with water deficit and high agricultural productivity. In front of the possibility of developing a simplified process for the production of biodiesel, such as in situ transesterification, which avoids the previous separation of the oil existing in the micelle, the present work aims to evaluate the kinetic behavior of extraction from castor oil using ethanol as solvent. In this context, experimental data were obtained about the kinetic from castor oil using ethanol in several conditions of temperature, as well as, fitting mathematical models able to describe the kinetic of the system castor-oil-ethanol. The castor seed used in the work were characterized about its humidity, oil content and acidity, having been obtained $4.86 \%, 43.3 \%$ and $2.1 \%$, respectively. The experiments were carried out in batch using sealed Erlenmeyer flasks in a thermostatic bath with reciprocal agitation to investigate the extraction process at different temperatures $\left(25,35\right.$ and $\left.45^{\circ} \mathrm{C}\right)$ and solid-liquid ratio equal to $0.08(\mathrm{~g} / \mathrm{ml})$. The percentage extractions were quantified in times of $15,30,45,60,120,180,240,300,480,600$ and $1440 \mathrm{~min}$. For description of kinetics extraction, the fit of three different kinetic models to the experimental data was tested, pseudo-first order (PFO), pseudo-second order (PSO) and Patricelli. From the calculation of the corrected Akaike information criterion (AICc), the PSO model was the one that best described the extraction kinetics. In this way, the results obtained in this work contribute to expand the knowledge about the extraction process of castor oil with ethanol as solvent.
\end{abstract}

Keywords: Solid-liquid extraction; Mathematical modeling; Biodiesel.

\section{Resumo}

A sensibilização para questões energéticas e ambientais decorrentes da queima de combustíveis fósseis incentivou a busca por materiais, insumos e fontes renováveis de energias. O biocombustível é uma dessas fontes renováveis e é produzido a partir de óleos vegetais extraídos de matérias primas como a mamona (Ricinus communis). Ela tem sido investigada como matéria-prima devido ao alto teor de óleo na semente, a possibilidade de plantio em regiões com déficit hídrico e à sua elevada produtividade agrícola. Diante da

'Universidade Federal da Fronteira Sul, Cerro Alrgo, Rs, Brasil - suzanaboligonn@gmail.com.

"Universidade Federal da Fronteira Sul, Cerro Largo, RS, Brasil- scheranacarolina@hotmail.com.

I"Universidade Federal da Fronteira Sul, Cerro Largo, RS, Brasil- bruno.wenzel@uffs.edu.br. 
possibilidade de desenvolvimento de um processo simplificado para a produção de biodiesel, como o de transesterificação in situ, que evita a separação prévia do óleo presente na micela, o presente trabalho busca avaliar o comportamento cinético da extração do óleo de mamona empregando etanol como solvente. Nesse contexto, foram obtidos dados experimentais sobre a cinética da extração de óleo de mamona com etanol em diferentes condições de temperatura, bem como, ajustar modelos matemáticos capazes de descrever a cinética do sistema mamona-óleo-etanol. As sementes de mamona empregadas no trabalho foram caracterizadas acerca de sua umidade, teor de óleo e acidez, tendo sido obtido 4,86 \%, 43,3\% e 2,1\%, respectivamente. Os experimentos foram realizados em batelada utilizando frascos erlenmeyer selados em banho termostático com agitação recíproca para investigar o processo de extração em diferentes temperaturas $\left(25,35\right.$ e $\left.45^{\circ} \mathrm{C}\right)$ e razão sólido-líquido $0,08(\mathrm{~g} / \mathrm{mL})$. As extrações percentuais foram quantificadas em tempos de $15,30,45,60,120$, 180, 240, 300, 480, 600 e 1440 min. Para descrição da cinética de extração, foi testado o ajuste de três modelos cinéticos diferentes aos dados experimentais, pseudo-primeira ordem (PFO), pseudo-segunda ordem (PSO) e Patricelli. A partir do cálculo do critério de informação de Akaike corrigido (AICc) o modelo PSO foi o que melhor descreveu a cinética de extração. Deste modo, os resultados obtidos neste trabalho contribuem para ampliação dos conhecimentos acerca do processo de extração de óleo de mamona com etanol como solvente.

Palavras-chave: Extração sólido-líquido; Modelagem matemática; Biodiesel. 


\section{Introduction}

The depletion of oil reserves, their high price and greenhouse gas emissions, make renewable energy sources more attractive (MARCHETTI et al., 2007). Development in most countries depends on imported fossil fuels due to limited sources of resources, which means a high impact on their economy (CHIDAMBARANATHAN et al., 2020). In the last few years, the politics of several countries have guided the transition from the use of fossil fuels to biofuels (CONEJERO et al., 2017).

Biodiesel is one of the options for reducing dependence on oil reserves, because, in addition to being environmentally relevant because it is biodegradable, it has less toxicity, a higher flash point, more ecological emissions (carbon neutral), irrelevant sulfur and is produced from renewable raw materials (DEMIRBAS, 2007; POUSA et al., 2007; ABOELAZAYEM et al., 2018; ROY et al., 2020).

In this way, raw materials are sought that reduce the cost of biodiesel production. Among the oilseeds that can be used in production, the castor bean (Ricinus communis) stands out due to the high oil content present in the seed (40 - 55\%) compared to other oilseeds (soy: 15 - 20\%; sunflower: $25-35 \%$ ), high productivity, relative resistance to water stress, and its use as an energy source does not compete with food production (MELLER et al., 2014; IICA, 2007; BELTRÃO, 2003; KEERA et al., 2018, ATABANI et al., 2012).

Approximately, $95 \%$ of castor seed is used in oil extraction, which consists mainly of acid triglycerides, which are not edible (GARCíA et al., 2017).

Castor bean is a perennial shrub with rapid growth and branches, reaching over 3 meters in height (ABOELAZAYEM et al., 2018). Currently, castor bean is widely planted in dry areas of the tropics and subtropics and in areas that have seasons with high temperatures (DAS et al., 2018). The global production of castor oil is about 1.8 million tons per year. The main producers are India, China and Brazil (ATTIA et al., 2018).

For the production of biodiesel, it is necessary, firstly, to extract the oil from the oilseed. This process requires the application of a solvent to remove a constituent present in a solid (GREEN and PERRY, 2008). Solvent extraction is characterized by mass transfer, 
where the seed is firstly ground and after, it is placed in contact with the solvent, so that the oil is transferred from the solid phase to the liquid phase (ANDRADE et al., 2013).

There are many factors that influence the rate of oil extraction, such as the particle size of the solid, the type of solvent, temperature and hydrodynamic conditions (GREEN and PERRY, 2008). Different extraction methods are applied due to the great variability of sources of oilseed raw materials. The most usual method is solvent extraction, with the use of hexane currently standing out. Among the problems involving the use of hexane in extraction is its high degree of toxicity, flammability and volatility, which reinforces the need to seek alternative solvents for the process (SAWADA et al., 2014). On the other hand, ethanol is a biodegradable and nontoxic solvent (in small quantities), which has great potential in oil extraction and, therefore, it is possible to replace hexane without major loss of yield (TOMAZIN JR, 2008).

Therefore, for the production of biodiesel, where a short-chain alcohol is used as a process reagent, characteristic of the transesterification reaction (KNOTHE, 2010), it is interesting to investigate the possibility of using an alcohol as an extraction solvent for castor oil, as it can be used as a reagent for the transesterification process. Accordingly, intermediate stages of oil separation/purification are avoided.

Transesterification has been considered the best method for the production of biodiesel, and can be described as a reaction in which a vegetable oil or animal fat, combined with an alcohol, such as ethyl or methanol, in the presence of a catalyst, produces esters ethyl/methyl and glycerin (PRADANA et al., 2017; KUCEK, 2004)

In the process of in situ transesterification, alcohol acts as a solvent and reagent, in a continuous process. On the other hand, in the conventional process, extraction takes place in a previous step, of solid-liquid extraction. Only after this process, the transesterification reaction is performed using the oil already separated (DOMINGUES, 2017; HAAS et al., 2007; HINCAPIÉ et al., 2011).

In an energy analysis of few biodiesel production routes, Sangaletti-Gerhard et al. (2014) demonstrated that the direct process (in situ), from an alcoholic micelle rich in soybean oil, had the potential to produce biodiesel competitively. 
Based on the above, the present work aims to evaluate the kinetic behavior of the extraction of castor oil using ethanol as a solvent. The data were used to adjust kinetic models and extraction isotherms, which enable the description of the extraction process in continuous systems, aiming the increasing of scale.

\section{Material and methods}

\subsection{Materials and characterization}

The castor seeds employed in the study were supplied by the EMBRAPA Algodão. The material was fragmented with the assist of an analytical mill in order to reduce the size of the particles and obtain the cake for extraction. The humidity content (by drying the seeds in an oven at $90^{\circ} \mathrm{C}$ for $24 \mathrm{~h}$ ), oil content (through an oil and grease extractor using PA petroleum ether as a solvent) and acidity (titration with $\mathrm{NaOH}$ ), as shown in Table 1 . Anhydrous ethanol (99.9\%) was used as the extraction solvent in all experiments.

Table 1 - Characterization of castor seed used at work

\begin{tabular}{lcc}
\hline Parameter & Value (\%) & Method \\
\hline Humidity & $4.86 \pm 0.24$ & AOCS Ac 2-41 \\
Oil Content & $43.36 \pm 1.62$ & AOCS Ac 3-44 \\
Acidity (free fatty acids) & 2.1 & AOCS Ac 5-41 \\
\hline
\end{tabular}

\subsection{Experimental and analytical methods}

The experiments were carried out in batches, using sealed $250 \mathrm{ml}$ Erlenmeyer flasks, in a thermostatic bath with reciprocal agitation. Pre-established volumes of ethanol were added to the recipient and then pre-heated to the determined temperature, in the Dubnoff bath. Fragments of castor bean seed were inserted into the extraction system, according to the determined solid/liquid ratio $\left(R^{\prime}\right)$.

After extraction time, the mixture was vacuum filtered. The solid phase resulting from the experiment was used to determine the amount of oil not extracted, according to Method 
AOCS Ac 3-44 (using oil and grease extractor and petroleum ether as solvent). From this result, the extraction yield $(E)$ was calculated, based on the knowledge of the initial oil content present in the seed (see Table 1).

In this work, considering the use of adjustment of mathematical models for the extraction process, the experimental data were presented in the form of absolute fractions of oil in the solid and liquid phases, $X$ and $Y$, according to Equation $(1 a, b)$.

$$
Y=R E ; \quad X=X_{0}(1-E)
$$

Where: $X$ is the absolute fraction of oil in the solid phase ( $g$ oil/g solid), $Y$ is the absolute fraction of oil in the liquid phase ( $\mathrm{g}$ oil/g ethanol), $E$ it is the extraction yield (dimensionless);

$X_{0}=0.7656 \frac{g \text { oil }}{g \text { solid }}$ is the initial absolute fraction of oil in the seeds, calculated from the initial oil fraction, $x_{0}=0.4336 \frac{g \text { oil }}{g \text { (oil }+ \text { solid })}$ (see Table 1), for the relation $X_{0}=\frac{x_{0}}{1-x_{0}} ; R$ is the oil:ethanol mass ratio used in the system, calculated by the ratio $R=R^{\prime} \frac{x_{0}}{\rho_{S}}$, where $\rho_{S}=$ $0.789 \frac{\mathrm{g}}{\mathrm{ml}}$ is the density of ethanol; and $R^{\prime}$ is the liquid-solid ratio of the system [ $\mathrm{g}$ (oil + solid)/ml ethanol].

The extraction kinetics experiments used a fixed solid-liquid ratio, with the extraction time varying between 15 and 1440 minutes, as shown in Table 2.

Table 2 - Kinetic experiments for extraction of castor oil with ethanol

\begin{tabular}{cccc}
\hline $\begin{array}{c}\text { Group of } \\
\text { experiments }\end{array}$ & $\begin{array}{c}\text { Temperature } \\
\left({ }^{\circ} \mathbf{C}\right)\end{array}$ & $\begin{array}{c}\text { Solid-liquid } \\
\text { Ratio } \boldsymbol{R}^{\prime} \\
(\mathbf{g} / \mathbf{m l})\end{array}$ & Time, t (min) \\
\hline 1 & 25 & & $15,30,45,60$, \\
2 & 35 & 0.08 & $120,180,300$, \\
3 & 45 & & 480,600 and \\
1440
\end{tabular}


The methodology for analytical determination of the oil content in the seed was adapted from the AOCS Method Ac 3-44, which uses oil and grease extraction equipment. The procedure consisted of heating about $160 \mathrm{ml}$ of the petroleum ether solvent, at $80^{\circ} \mathrm{C}$, in a bottle of the reboiler system. The sample was wrapped in a cellulose filter, placed in a mobile capsule inside the equipment and subsequently immersed in the boiling solvent for $4 \mathrm{~h}$. After this time, the capsule/sample was suspended for a dripping/washing phase with solvent for an additional $2 \mathrm{~h}$. The third step consisted of recovering the solvent, being condensed in an alternative recipient. After the recovery phase, the reboiler flask (which was previously weighed) was placed in an oven for total evaporation of the solvent. Then, the flask containing only the extracted oil was sent to a desiccator for cooling, and the mass was determined on an analytical balance. The oil content in the sample was calculated based on the mass of oil extracted (difference between the mass of the flask before and after extraction) and the sample mass used.

\subsection{Mathematical Background}

Kinetic models

To describe the kinetics of the extraction process, the three kinetic models in Table 3 were tested, which has been used the most in literature (AMARANTE et al., 2014; TODA et al., 2016; DAGOSTIN et al., 2015; CHAN et al., 2014; PATRICELLI et al., 1979; PEREZ et al., 2011; BAÜMLER et al., 2010; MENEZES et al., 2018):

PFO: Mass transfer velocity proportional to the difference in oil content in the solid phase with the one that would have in an equilibrium situation.

PSO: Mass transfer velocity proportional to the quadratic difference of the oil content in the solid phase in relation to equilibrium.

Patricelli et al. (1979): Supposes that extraction occurs through two distinct mechanisms: washing (sub-index L) and diffusion (sub-index S). The washing mechanism is responsible for extracting the available oil portion in a superficial layer, while the diffusion extracts the oil present in the interstices of the solid phase. 
Table 3 - Kinetics models, initial conditions and adjusted parameters

\begin{tabular}{|c|c|c|c|c|}
\hline Models & $\begin{array}{c}\text { Differential } \\
\text { Equation* }\end{array}$ & Initial Condition & Parameters & Eq. \\
\hline $\begin{array}{l}\text { Pseudo-first } \\
\text { order (PFO) }\end{array}$ & $\frac{d X}{d t}=-K\left(X-X_{e q}\right)$ & $X(t=0)=X_{0}$ & $K ; X_{e q}$ & (2) \\
\hline $\begin{array}{c}\text { Pseudo- } \\
\text { second } \\
\text { order (PSO) }\end{array}$ & $\frac{d X}{d t}=-K\left(X-X_{e q}\right)^{2}$ & $X(t=0)=X_{0}$ & $K ; X_{e q}$ & (3) \\
\hline Patricelli & $\begin{array}{l}\frac{d X_{S}}{d t} \\
=-K_{S}\left(X_{S}-X_{e q, S}\right) \\
\frac{d X_{L}}{d t} \\
=-K_{L}\left(X_{L}-X_{e q, L}\right)\end{array}$ & $\begin{array}{l}X_{S}(t=0)=f X_{0} \\
\quad X_{L}(t=0) \\
\quad=(1-f) X_{0}\end{array}$ & $\begin{array}{c}K_{S i} ; X_{e q, S i} \\
K_{L} ; X_{e q, L} ; f\end{array}$ & $(4 a, b)$ \\
\hline
\end{tabular}

* Obtained from material balance of the solid phase.

In the equations in Table 3: $K$ is the global mass transfer coefficient $[\mathrm{g}$ solid/( $\mathrm{g}$ oil.min)]; and $X_{e q}$ is the absolute fraction of oil in the solid phase in an equilibrium situation (g oil/g solid). The sub-indices $L$ and $S$ refer to the different mechanisms of the Patricelli model and the parameter $f$ refers to the fraction of the oil, in the initial condition, which is subject to extraction by the washing mechanism.

For solutions of the ordinary differential equation (ODE) (or ODE systems), the method described by Shampine and Reichelt (1997) was used. In this way, the absolute fraction of oil in the solid phase through time can be obtained, with an adequate value for the adjustable parameters. Knowing the values of $X$ over time, the absolute fraction in the liquid phase, $Y$, can be calculated from the Equation (5).

$$
Y=R\left(1-\frac{X}{X_{0}}\right)
$$

Solution, fitting and selection of models

The adjustments of the models to the experimental data were performed through a Matlab R2015a routine. The Trust-region-reflective optimization algorithm was used (Coleman and Li, 1996), in order to minimize the normalized least squares objective function, Fobj (Equation (7)). In order to obtain information about the quality of the data fitting, the 
determination coefficient $\left(\mathrm{R}^{2}\right)$ was calculated for each experimental condition according to Equation 6.

$$
\begin{gathered}
R^{2}=1-\frac{\sum_{i=1}^{n}\left[(X)_{\text {exp }}^{i}-(X)_{\text {mod }}^{i}\right]^{2}}{\sum_{i=1}^{n}\left[(X)_{\text {exp }}^{i}-(\bar{X})_{\text {exp }}\right]^{2}} \\
F_{o b j}=1-R^{2}
\end{gathered}
$$

Where: $n$ is the number of experimental data to be adjusted by the model; the subindex "exp" refers to the experimental values, while the sub-index "mod" refers to the values predicted by the mathematical model in question; and the superscript " $i$ " refers to the standard numbering of the experimental data vector.

To select the best model, the corrected Akaike information criterion (AICC) was calculated using Equation (8). The AICc was employed to determine the most suitable model for the system, as it takes into account the accuracy, precision and ability of different models, with different numbers of adjustable parameters (AKAIKE, 1973). The AICc consists of a correction of the Akaike information criterion (AIC) for small samples $(n / n p<40)$ (HURVICH and TSAI, 1990). The selection of the best mathematical model consisted of the adoption of the one with the lowest AICc value.

$$
A I C C=n \ln \left\{\frac{1}{n} \sum_{i=1}^{n}\left[(X)_{\text {exp }}^{i}-(X)_{\text {mod }}^{i}\right]^{2}\right\}+2(n p+1)\left(1+\frac{n p+2}{n-n p-2}\right)
$$

In Equation (8): $n p$ is the number of parameters associated with the model adjustment.

\section{Results and discussion}

\section{Extraction kinetics: fitting and model selection}

From the experimental data of the extraction kinetics at temperatures of 25,35 and $45^{\circ} \mathrm{C}$, the kinetic models presented in Table 3 were adjusted by non-linear regression.

The Table 4 presents an abstract of the results: number of adjusted parameters (np), number of experimental data used in the adjustment ( $n$ ) (which includes different temperatures), regression determination coefficient $\left(R^{2}\right)$ and the Akaike information criterion corrected (AICC) for each model. 
As can be seen in the Table 4, Patricelli's model presented the best correlation coefficient, but it has a high number of adjustable parameters (15). On the other hand, the PSO model presented a slightly lower $\left(R^{2}\right)$, however, with a smaller number of parameters (5). The PFO model has a number of parameters equal to the PSO, though a lower predictive power.

In cases where models with different numbers of parameters are used, to evaluating the most appropriate, the AICc has been used, as it allows the comparison of mathematical models with different number of parameters (MONTE BLANCO et al., 2017). The AICc includes information on accuracy, as well as precision and the ability of different equations to describe experimental data (AKAIKE, 1973).

The PSO model presented the lowest value of the corrected Akaike information criterion (AICc), as shown in Table 4, suggesting that it is the most suitable for describing the kinetics of extraction of castor oil with ethanol.

Table 4 - Information about the (fitting) quality of the kinetic models at different temperatures

\begin{tabular}{|c|c|c|c|c|c|c|c|}
\hline \multirow{2}{*}{ Model } & \multicolumn{4}{|c|}{ Determination Coefficient, $\mathbf{R}^{2}$} & \multirow[b]{2}{*}{$n p$} & \multirow{2}{*}{$\boldsymbol{n}$} & \multirow{2}{*}{$\mathrm{AICc}$} \\
\hline & $25^{\circ} \mathrm{C}$ & $35^{\circ} \mathrm{C}$ & $45^{\circ} \mathrm{C}$ & Final & & & \\
\hline PFO & 0.9606 & 0.9434 & 0.9940 & 0.9678 & 6 & 33 & -88.47 \\
\hline PSO & 0.9884 & 0.9752 & 0.9917 & 0.9856 & 6 & 33 & -114.09 \\
\hline Patricelli & 0.9909 & 0.9802 & 0.9972 & 0.9899 & 15 & 33 & -79.27 \\
\hline
\end{tabular}

Figure 1 shows the experimental results in comparison with the values predicted by the PSO model. It can be seen that the model was able to explain $98.6 \%$ of the data variability. 
Figure 1 - Experimental and predicted results by the PSO model $(\mathrm{R} 2=0.9856)$

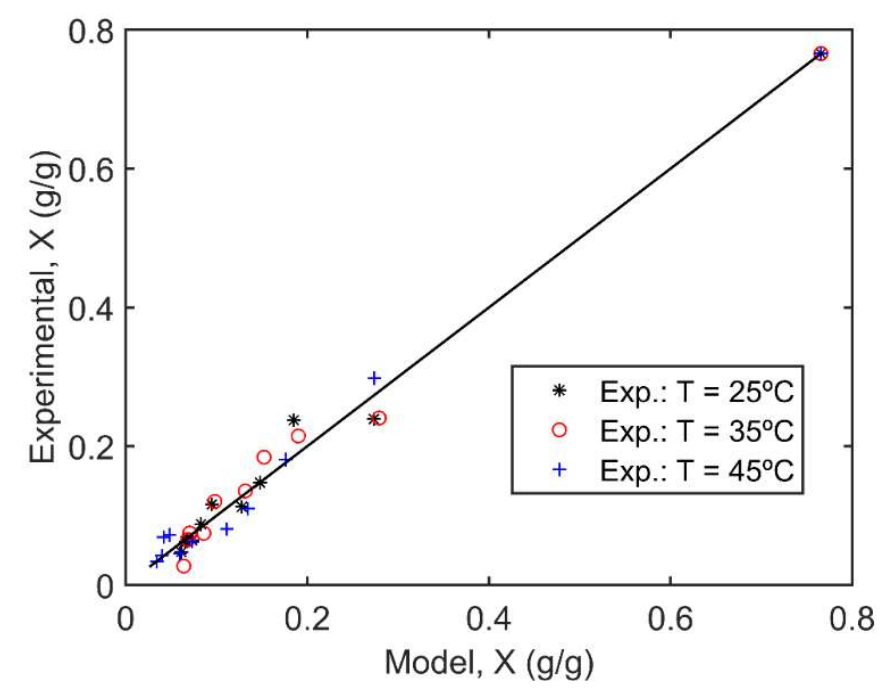

Extraction kinetics by the PSO model

Based on the conclusion of which PSO model presented a better description of the experimental data, Table 5 presents the values of the kinetic parameters selected in the adjustment. Figure 2 (a) shows the relative curves to the kinetic model and experimental data. It is observed that the extraction behavior at temperatures of 25 and $35^{\circ} \mathrm{C}$ has similar characteristics, while the temperature of $45^{\circ} \mathrm{C}$ presents a low performance level. These behaviors reflect the values of the parameters, according to Table 5.

Between the temperatures of 25 and $35^{\circ} \mathrm{C}$, both parameters $K$ and $X_{e q}$ increased. While an increase in the global mass transfer coefficient is expected with the increasing in temperature, the trend to the absolute mass fraction of equilibrium is decreasing. This behavior is due to the experimental uncertainties, as can be seen in Figure 2, where a result stands out far from the trend of the curve in the temperature of $35^{\circ} \mathrm{C}$. Another aspect to be considered is the relative proximity of both sets of experimental data. Considering this, the precision related to the adjustment of the parameters ends up being compromised.

On the other hand, the equilibrium fraction at a temperature of $45^{\circ} \mathrm{C}$ is the lowest of all, a fact that was expected. In general, as observed in Figure 2 (b), the temperature of 45 ${ }^{\circ} \mathrm{C}$ resulted in the best performance, supporting both the velocity and the achievement of a lower fraction of oil in the solid phase at the end of the process. 
Table 5 - Kinetic parameters of the PSO model

\begin{tabular}{lcccc}
\hline \multicolumn{1}{c}{ Parameter } & \multicolumn{3}{c}{ Temperature } \\
\hline \multicolumn{1}{c}{ Description } & Symbol/Unity & $25^{\circ} \mathrm{C}$ & $35^{\circ} \mathrm{C}$ & $45^{\circ} \mathrm{C}$ \\
\hline $\begin{array}{l}\text { Global mass transfer } \\
\text { coefficient }\end{array}$ & $K\left(\frac{g \text { solid }}{\text { g oil } \cdot \text { min }}\right)$ & 0.2156 & 0.2375 & 0.1835 \\
$\begin{array}{l}\text { Absolute mass } \\
\text { fraction in } \\
\text { equilibrium }\end{array}$ & $X_{e q}\left(\frac{g \text { oil }}{g \text { solid }}\right)$ & 0.05803 & 0.07400 & 0.03057 \\
\hline
\end{tabular}

Figure 2 - Extraction kinetics - experimental and predicted by the PSO model. (a) Absolute mass fraction of oil in the solid phase through time. (b) Yield over time
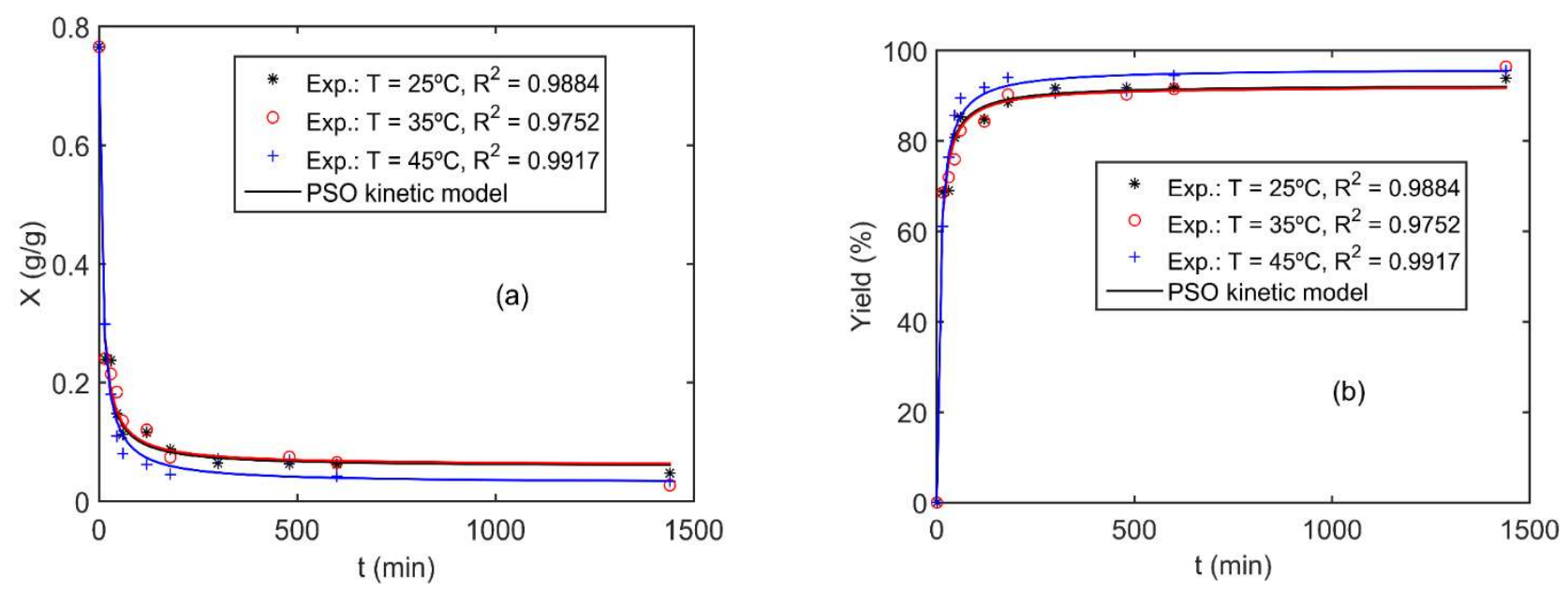

The results of kinetic extraction by PSO model can be compared to those obtained by Menkiti et al. (2015) regarding the extraction of oil from Terminalia Catappa L (almond tree-beach) with $\mathrm{N}$-hexane solvent, concluded that among the evaluated models (Elovich, hyperbolic and pseudo-second order), the PSO model defined better extraction of almond oil in the studied conditions. In addition, Menkiti et al. (2017) in his studies of chemistry and parametrics for extractivism and oil analysis using Terminalia Catappa L. kernel, when analyzing of statistical results, the pseudo-second order model presented higher values of $R^{2}$, better describing the extraction kinetic under analysis.

\section{Final Remarks}

In this work, the kinetics of the extraction process of castor oil with ethanol was evaluated at three different temperatures $\left(25,35\right.$ and $\left.45^{\circ} \mathrm{C}\right)$, with fixed solid-liquid ratio and 
extraction time varying between 15 and $1440 \mathrm{~min}$. From a nonlinear regression of three mathematical models for the experimental data, it was concluded that among the tested kinetic models, the Pseudo-Second Order model best described the behavior of the experimental data $\left(R^{2}=0.9856\right.$ and $\mathrm{AlCC}=$ -114.09). The PSO model, as well as the kinetic parameters obtained, can be used for the rational dimensioning of a solid-liquid extraction operation of castor oil in larger scales.

\section{Acknowledgments}

The Authors would like to thanks EMBRAPA Algodão (Dr. Liv S. Severino) for providing the castor seeds used in the study.

\section{References}

ABOELAZAYEM, O.; EL-GENDI, N. S.; ABDEL-REHIM, A. A.; ASHOUR, F; SADEK, M. A. Biodiesel production from castor oil in Egypt: Process optimisation, kinetic study, diesel engine performance and exhaust emissions analysis. Energy. 2018;157:843-852. Available from: https://doi.org/10.1016/j.energy.2018.05.202

AKAIKE, $\mathrm{H}$. Information theory and the maximum likelihood principle in 2nd International Symposium on Information Theory (B.N. Petrov and F. Cs ä ki, eds.). Akademiai Ki à do, Budapest.1973.

AMARANTE, R. C. A.; OLIVEIRA, P. M.; SCHWANTES, F. K.; MÓRON-VILLARREYES, J. A. Oil Extraction from Castor Cake Using Ethanol: Kinetics and Thermodynamics. Ind. Eng. Chem. Res. 2014;53:6824-6829. Available from: https://doi.org/10.1021/ie500508n

ANDRADE, J. K. S.; SILVA, G. F.; BARRETO, L. C. O; SANTOS, J. A. B. Estudo da cinética de secagem, extração, caracterização e estabilidade térmica do óleo das sementes de Maracujá do Mato (Passiflora Cincinnata Mast.). Rev. GEINTEC. 2013;3:283-291. Available from: https://doi.org/10.7198/geintec.v3i4.306

AOCS. AOCS Official Method Ac 2-41: Soybeans - Moisture and Volatile Matter. Em: Fats, Oils and Lipid Related Analytical Methods. [s.l.] American Oil Chemists' Society. 2009.

AOCS. AOCS Official Method Ac 3-44: Soybeans - Oil. Em: Fats, Oils and Lipid Related Analytical Methods. [s.l.] American Oil Chemists' Society. 2009.

AOCS. AOCS Official Method Ac 5-41: Free Fatty Acids in Soybeans.[s.l.] American Oil Chemists' Society. 2000.

ATABANI, A. E;; SILITONGA, A. S.; BADRUDDIN, I. A.; MAHLIA, T. M. I; MASJUKI, H. H.; MEKHILEF, S. A comprehensive review on biodiesel as an alternative energy resource and its characteristics. Renewable and Sustainable Energy Reviews. 2012;16(4):2070-2093. Available from: https://doi.org/10.1016/j.rser.2012.01.003 
ATTIA, A. M. A.; NOUR, M.; NADA, S. A. Study of Egyptian castor biodiesel-diesel fuel properties and diesel engine performance for a wide range of blending ratios and operating conditions for the sake of the optimal blending ratio. Energy Conversion and Management. 2018;174:364-377. Available from: https://doi.org/10.1016/j.enconman.2018.08.016

BAÜMLER, E. R.; CRAPISTE, G. H.; CARELLI, A. A. Solvent Extraction: Kinetic Study of Major and Minor Compounds. J Am Oil Chem Soc. 2010;87:1489-1495. Available from: https://doi.org/10.1007/s11746010-1637-3

BELTRÃO, N. E. M. Informações sobre o Biodiesel, em Especial Feito com o Óleo de Mamona. Embrapa

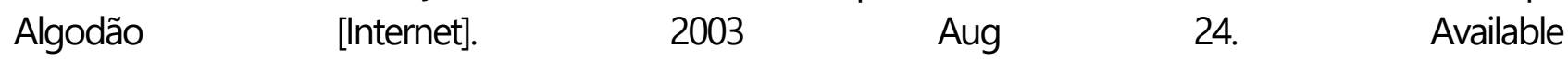
from: https://www.infoteca.cnptia.embrapa.br/handle/doc/273465.

CHAN, C. H.; YUSOFF, R.; NGOH, G. C. Modeling and kinetics study of conventional and assisted batch solvent extraction. Chemical Engineering Research and Design. 2014;92:1169-1186. Available from: https://doi.org/10.1016/j.cherd.2013.10.001

CHIDAMBARANATHAN, B.; GOPINATH， S.; ARAVINDRA, R.; DEVARAJ, A.; KRISHNAN, S. G.; JEEVAANANTHAN, J.K. S. The production of biodiesel from castor oil as a potential feedstock and its usage in compression ignition Engine: A comprehensive review. Materials Today: Proceedings. 2020. Available from: https://doi.org/10.1016/j.matpr.2020.03.205

COLEMAN, T. F.; LI, Y. An interior trust region approach for nonlinear minimization subject to bounds. SIAM J. Optim. 1996;6(2),418-445. Available from: https://doi.org/10.1137/0806023

CONEJERO, M. A.; CÉSAR, A. S.; BATISTA, A. P. The organizational arrangement of castor bean family farmers promoted by the Brazilian Biodiesel Program: A competitiveness analysis. Energy Policy. 2017;110:461-470. Available from: https://doi.org/10.1016/j.enpol.2017.08.036

DAS, M.; SARKAR, M.; DATTA, A.; SANTRA, A. K. An experimental study on the combustion, performance and emission characteristics of a diesel engine fuelled with diesel-castor oil biodiesel blends. Renewable Energy. 2018;119:174-184. Available from: https://doi.org/10.1016/j.renene.2017.12.014

DAGOSTIN, J. L. A.; CARPINÉ, D;; CORAZZA, M. L. 2015. Extraction of soybean oil using ethanol and mixtures with alkyl esters (biodiesel) as co-solvent. Kinetics and thermodynamics. Industrial Crops and Products. 2015;74:69-75. Available from: https://doi.org/10.1016/j.indcrop.2015.04.054

DEMIRBAS, A. Importance of biodiesel as transportation fuel. Energy Policy. 2007;35(9):4661-4670. Available from: https://doi.org/10.1016/j.enpol.2007.04.003

DOMINGUES, L. S. S. Produção de biodiesel de óleo de soja (Glycine max) via transesterificação in situ. [monography]. Bagé: Bacharel em Engenharia de Energia/UNIPAMPA; 2017.46p.

GARCÍA, M.; BOTELLA, L; GIL-LALAGUNA, N.; ARAUZO, J.; GONZALO, A.; SÁNCHEZ, J. L. Antioxidants for biodiesel: Additives prepared from extracted fractions of bio-oil. Fuel Processing Technology. 2017;156:407414. Available from: https://doi.org/10.1016/j.fuproc.2016.10.001 
GREEN, D. W; PERRY, R. H. Perry's Chemical Engineers' Handbook. McGraw-Hill Book Company. 2008. 8ed.

HAAS, M. J.; SCOTT, K. M.; FOGLIA, T. A.; MARMER, W. N. The general applicability of in situ transesterification for the production of fatty acid esters from a variety of feedstocks. J Am Oil Chem Soc. 2007;84:963-970. Available from: https://doi.org10.1007/s11746-007-1119-4

HINCAPIÉ, G.; MONDRAGON, F.; LÓPEZ, D. P. Conventional and in situ transesterification of castor seed oil for biodiesel production. Fuel. 2011;90(4):1618-1623. Available from:

https://doi.org/10.1016/j.fuel.2011.01.027

HURVICH, C. M.; TSAI, C. L Model selection for least absolute deviations regression in small samples. Statistics \& Probability Letters. 1990;9(3):259-265. Available from: https://doi.org/10.1016/0167-7152(90)90065-F

INSTITUTO INTERAMERICANO DE COOPERAÇÃO PARA A AGRICULTURA [Internet]. Brasil: Informe sobre a situação e perspectivas da agroenergia e dos biocombustíveis no Brasil. 2007. Available from: http://cmsdespoluir.cnt.org.br/Documents/PDFs/ICA-\%20biocombustibles.pdf

KEERA, S. T.; EL SABAGH, M. E;; TAMAN, A. R. Castor oil biodiesel production and optimization. Egyptian Joumal of Petroleum. 2018;27(4):979-984. Available from: https://doi.org/10.1016/j.ejpe.2018.02.007

KNOTHE, G.; KRAHL, J.; GERPEN, J. The Biodiesel Handbook. Champaign - USA: AOCS Press; 1:1-494. 2010.

KUCEK, K. T. Otimização da transesterificação etílica do óleo de soja em meio alcalino [Dissertation]. Curitiba: Mestrado no Programa de Pós-Graduação em Química/UFPR; 2004. 123 p.

MARCHETTI, J. M.; MIGUEL, V. U.; ERRAZU, A. F. Possible methods for biodiesel production. Renewable and Sustainable Energy Reviews. 2007;11(6):1300-1311. Available from: https://doi.org/10.1016/..rser.2005.08.006

MELLER, E;; GREEN, U;; AIZENSHTAT, Z;; SASSON, Y. Catalytic deoxygenation of castor oil over Pd/C for the production of cost effective biofuel. Fuel. 2014;133:89-95. Available from: https://doi.org/10.1016/j.fuel.2014.04.094

MENEZES, M. L; JOHANN, G.; DIÓRIO, A.; PEREIRA, N. C.; SILVA, E. A. Phenomenological determination of mass transfer parameters of oil extraction from grape biomass waste. Journal of Cleaner Production. 2018;176:130-139. Available from: https://doi.org/10.1016/j.jclepro.2017.12.128

MENKITI, M. C.; AGU, C. M.; UDEIGWE, T. K. Extraction of oil from Terminalia catappa L: Process parameter impacts, kinetics, and thermodynamics. 2015;77:713-723. Available from: https://doi.org/10.1016/j.indcrop.2015.08.019

MENKITI, M. C.; AGU, C. M.; UDEIGWE, T. K. Kinetic and parametric studies for the extractive synthesis of oil from Terminalia catappa L. kernel. Reac Kinet Mech Cat. 2017;120:129-147. Available from: https://doi.org/10.1007/s11144-016-1101-y

MONTE BLANCO, S. P. D.; SCHEUFELE, F. B; MÓDENES, A. N.; ESPINOZA-QUIÑONES, F. R; MARIN, P; KROUMOV, A. D.; et al. Kinetic, equilibrium and thermodynamic phenomenological modeling of reactive dye 
adsorption onto polymeric adsorbent. Chemical Engineering Journal. 2017;307:466-475. Available from: https://doi.org/10.1016/..cej.2016.08.104

PATRICELLI, A; ASSOGNA, A; CASALAINA, A; EMMI, A; SODINI, G. Fattori che influenzano l'estrazione dei lipidi da semi decorticati di girasole. La Rivista Italiana Delle Sostanze Grasse. 1979;56:136-142.

PRADANA, Y.S.; HIDAYAT, A; PRASETYA, A; BUDIMAN, A. Biodiesel production in a reactive distillation column catalyzed by heterogeneous potassium catalyst. Energy Procedia. 2017;143:742-747. Available from: https://doi.org/10.1016/j.egypro.2017.12.756.

PEREZ, E. E; CARELLI, A. A; CRAPISTE, G. H. Temperature-dependent diffusion coefficient of oil from different sunflower seeds during extraction with hexane. Journal of Food Engineering. 2011;105(1):180-185. Available from: https://doi.org/10.1016/j.jfoodeng.2011.02.025

POUSA, G. P. A. G.; SANTOS, A. L. F; SUAREZ, A. Z History and policy of biodiesel in Brazil. Energy Policy. 2007;35(11):5393-5398. Available from: https://doi.org/10.1016/j.enpol.2007.05.010

ROY, T; SAHANI, S; SHARMA, Y. C. Green synthesis of biodiesel from Ricinus communis oil (castor seed oil) using potassium promoted lanthanum oxide catalyst kinetic, themmodynamic and environmental studies. Fuel. 2020;274. Available from: https://doi.org/10.1016/j.fuel.2020.11764

SANGALETTI-GERHARD, N.; ROMANELU, T. L; VIEIRA, T. M. F. S; NAVIA, R; D'ARCE, M. A. B. R. Energy flow in the soybean biodiesel production chain using ethanol as solvent extraction of oil from soybeans. Biomass and Bioenergy. 2014;66:39-48. Available from: https://doi.org/10.1016/j.biombioe.2014.04.004

SAWADA, M. M.; LOPES, L; TODA, T. A; RODRIGUES, C. E. C. Effects of different alcoholic extraction conditions on soybean oil yield, fatty acid composition and protein solubility of defatted meal. Food Research Intemational. 2014;62:662-670. Available from: https://doi.org/10.1016/j.foodres.2014.04.039

SHAMPINE, L. F; REICHELT, M. W. The MATLAB ODE Suite. SIAM Journal on Scientific Computing. 1997;18(1):1-22. Available from: https://doi.org/10.1137 / S1064827594276424

TODA, T. A.; SAWADA, M. M.; RODRIGUES, C. E. C. Kinetics of soybean oil extraction using ethanol as solvent: Experimental data and modeling. Food and Bioproducts Processing. 2016;98:1-10. Available from: https://doi.org/10.1016/j.fbp.2015.12.003

TOMAZIN JUNIOR, C. Extração de óleo de soja com etanol e transesterificação etílica na miscela. [dissertation]. Piracicaba: Mestrado no Programa de Pós-Graduação em Ciências/USP; 2008. 72 p. 